Joseph A. Clougherty

The International Drivers of Domestic Airline Mergers in Twenty Nations:

Integrating Industrial Organization and International Business

SP I| $2005-06$

April 2005

ISSN Nr. $0722-6748$

Research Area

Markets and Political Economy

Research Unit

Competitiveness and Industrial Change
Forschungsschwerpunkt

Markt und politische Ökonomie

Abteilung

Wettbewerbsfähigkeit und industrieller Wandel 
Zitierweise/Citation:

Joseph A. Clougherty, The International Drivers of Domestic Airline Mergers in Twenty Nations: Integrating Industrial Organization and International Business, Discussion Paper SP II 2005 - 06, Wissenschaftszentrum Berlin, 2005.

Wissenschaftszentrum Berlin für Sozialforschung gGmbH,

Reichpietschufer 50, 10785 Berlin, Germany, Tel. (030) 25491 - 0 Internet: www.wz-berlin.de 


\section{The International Drivers of Domestic Airline Mergers in Twenty Nations: Integrating Industrial Organization and International Business}

by Joseph A. Clougherty*

The domestic airline merger phenomenon of the late 1980s and early 1990s sparked a great deal of Industrial Organization (IO) literature; yet, that literature neglected non-US domestic mergers and potential for international competitive gains. Using an International Business perspective to complement an 10 analysis, I argue that factoring international competitive incentives helps explain domestic airline merger activity. A Cournot model of airline competition illustrates that domestic mergers, via enhanced domestic networks and reduced domestic competition, generate international competitive gains. Further, empirical tests_using a structural-equations approach on panel data covering international city-pair market segments-support domestic mergers improving international competitiveness.

Keywords: airline-mergers, imperfect-competition, international-determinants

JEL Classification: L13, F14, L93

I wish to thank anonymous referees, Timothy N. Cason and Vai-Lam Mui, as well as a number of other individuals (Harry Barkema, Jonathan Beck, Martin Dresner, Tomaso Duso, Jean-Francois Hennart, Elisabeth Mueller, Tae H. Oum, Jong-Hun Park, Michael W. Pustay, Isabel Schnabel and Bernard Yeung) and seminar participants (Academy of International Business, SFB-TR15 Conference in Gummersbach-Germany, and University of Wyoming) for helpful comments and suggestions. In addition Christopher Xitco helped with bibliographic referencing, and the Boeing Company provided complimentary data. 
Was die inländischen Fluglinien in 20 Ländern zur Fusion getrieben hat. Eine integrierte industrieökonomische und betriebswirtschaftliche Analyse des internationalen Wettbewerbs

In der Industrieökonomik hat das Phänomen von Fusionen inländischer Fluggesellschaften in den späten 1980er und frühen 1990er Jahren viel wissenschaftliche Literatur angeregt. Die einschlägigen Forschungsarbeiten behandeln jedoch ausschließlich inländische Fusionen in den U.S.A. und lassen damit den Aspekt des internationalen Wettbewerbs außer Acht. In dieser Untersuchung, die die industrieökonomische Analyse um die Perspektive der internationalen Betriebswirtschaft ergänzt, wird gezeigt, dass die Anreize des internationalen Wettbewerb in das Erklärungsmodell für nationale Fusionen von Fluglinien integriert werden können. Anhand eines Cournot-Modells des Wettbewerbs zwischen Fluggesellschaften kann dargelegt werden, wie Fusionen zu einem erweiterten inländischen Netz an Flugverbindungen und verminderten Konkurrenzdruck im Inland führen und so die Position der fusionierten Fluglinie im internationalen Wettbewerb stärken. Dieses Ergebnis wird von empirischen Tests, die eine Struckturvergleichsmethode für Paneldaten über einen internationalen Städtevergleich der Marktsegmente verwenden, gestützt. 


\section{INTRODUCTION}

A number of domestic airline mergers - the TWA/Ozark and Northwest/Republic pairings being most notable-occurred in the late 1980s and early 1990s (Pustay, 1992). The high profile nature of these mergers led to a substantial amount of Industrial Organization (IO) literature that split along the familiar market-power (Kim and Singal, 1993; Werden et al., 1991; Borenstein, 1989; U.S. General Accounting Office, 1988) versus efficiency-gains (Brueckner and Spiller, 1991, 1994; Brueckner et al., 1992; Levine, 1987) lines. As for what drove merger activity, one could extrapolate the following from the literature: the marketpower camp favoring merged airlines’ ability to raise fares via reduced competition, and the efficiency-gains camp favoring merged airlines’ ability to reduce costs via hub-and-spoke networks. Yet, the IO literature was less concerned with merger motives and more concerned with social welfare implications. Beyond understudying motivations, the literature neglected that domestic airline mergers involved significant international dimensions.

While the IO literature focused on US domestic merger activity, the domestic airline merger phenomenon was actually cross-national in scope as domestic mergers occurred in many nations beyond the US: e.g., British Air acquired British Caledonia, Air France acquired Air Inter. ${ }^{1}$ Accordingly, the term 'cross-national' refers here to domestic airline merger activity (where the acquirer and target have operations in the same home-nation) not being restricted to one nation (i.e., the US). Nevertheless, airline consolidation has certainly taken on different forms: international airline alliances (see Brueckner (2003) for a short literature review) commenced in the early 1990s; an additional wave of domestic consolidation (e.g., Air Canada/Canadian; American/TWA; JAL/Japan Air Systems) occurred in the late 1990s; and cross-border acquisitions (e.g., SwissAir/Sabena; AirFrance/KLM) have been a recent manifestation. Yet, this study focuses simply on the domestic airline mergers of the late 1980s and early 1990s. Moreover, the point here is that 
the IO literature responding to airline merger activity did not take into account the crossnational scope of the phenomenon.

The IO literature also focused on the domestic competitive effects of airline mergers; thus, paying little heed to any strategic relationship between domestic mergers and international competitive outcomes. Recent 'revisionist' IO articles-Morrison and Winston (2000) and Clougherty (2002)—begin exploring the international competitive incentives behind domestic airline mergers, but restrict the scope to US mergers. Neglecting international competitive effects owes in part to the focus on US merger activity, as sizable US domestic markets favor domestic competitive incentives primarily driving merger behavior. However, neglecting international incentives appears problematic when one realizes the cross-national nature of the airline merger phenomenon. Many mergers occurred in nations where the economic-weight of international markets outweighs that of domestic markets; in such markets, firms would seemingly consider the international incentives behind domestic actions. ${ }^{2}$ Domestic airline mergers also occurred in some nations (e.g., France) prior to domestic deregulation; in such markets, mergers might seemingly be a response to international competitive realities—-not regulated domestic realities.

In sum, a comprehensive study of the world domestic-airline merger phenomenon requires understanding both the cross-national scope and the international competitive incentives behind domestic merger activity. The reasoning and analysis here are primarily economic (IO in particular) in nature; yet, a subtext throughout the work is that the International Business (IB) literature complements an IO analysis. Specifically, two fundamental tenets of IB (international implications factor in the domestic actions of businesses, and the analytical lens should consider cross-national business activity—Nehrt et

\footnotetext{
${ }^{1}$ See Table 2 later in the paper for a complete list of domestic airline mergers within the data set employed here.

${ }^{2}$ Ninety percent of US airlines' traffic is domestic, but Canadian carriers find international markets equaling the size of domestic markets, and smaller nations--like the Netherlands--find international markets far outweighing domestic markets.
} 
al., 1970) might have helped the IO literature factor the cross-national scope and the international competitive incentives involved with domestic airline mergers.

The paper consists of one overriding main contention - domestic airline mergers were driven by international competitive incentives in addition to the domestic competitive incentives focused on by the pre-existing literature - and the logic behind this argument involves two causal paths. First, a network-expansion effect where domestic airline mergers enhance domestic networks, larger domestic networks generate crucial passenger traffic that increases the efficiency of international operations, and more-efficient airlines earn greater traffic and profits in imperfectly competitive international markets. Second, a networkconsolidation effect where domestic airline mergers eliminate domestic competition, less domestic competition allows airlines to increase the efficiency of domestic operations (an input into international service), and airlines with more efficient domestic operations earn greater traffic and profits in imperfectly competitive international markets. In short, airlines — circa the late 1980s_-faced a strategic incentive to both expand and consolidate their domestic network operations via mergers in order to improve international competitiveness.

In order to both frame the main contention and formally set testable propositions, the paper proceeds as follows. The next section nests the main contention within the relevant literature while discussing three necessary conditions for the contention to hold and the two causal paths by which domestic airline mergers promote international competitiveness. The subsequent section presents a simple Cournot model that captures the essentials of international airline competition and helps generate two formal propositions that illustrate the network-expansion and network-consolidation effects. The last substantive section presents a methodological approach - drawing from both panel data and structural equations procedures - to empirically estimate the impact and causal paths by which domestic airline mergers affect international competitive outcomes. 


\section{THREE NECESSARY CONDITIONS \& TWO CAUSAL PATHS}

The paper's fundamental argument - that domestic airline mergers were driven by international competitive incentives as well as domestic incentives - rests upon the presence of three general economic conditions (segmentation of international and domestic markets; imperfectly competitive markets; and existence of economies) identified by Krugman (1984) as necessary for a national-champion rationale to hold.

First, domestic city-pair markets have traditionally been the exclusive territory of home-nation airlines (Pustay, 1992), while international city-pair markets generally exhibit significant competitive barriers due to their traditionally being the exclusive territory of the pair-nation’s designated airlines (de Murias, 1989). The distinction between domestic and international markets is, hence, an important one-one that is mirrored in a number of other studies (e.g., Pustay, 1989; Weisman, 1990; Ramamurti \& Sarathy, 1997; Clougherty, 2001, 2002). Further, it is generally agreed that city-pair markets are the appropriate level-ofanalysis for airline industry competition (Morrison \& Winston, 1987). While the empirical analysis in this work is faithful to the importance of analyzing city-pair outcomes, the immediate point is that classifying individual city-pair markets into domestic and international markets adds important heuristic insights.

Second, imperfectly competitive international markets provide an incentive for airlines to engage in efficiency-enhancing endeavors since profits accrue to low-cost providers. Despite the liberalization of the past two decades, international airline markets remain rather restricted. The regulatory and competitive entry barriers involved with international markets combine to ensure that strategic behavior determines market outcomes; i.e., entry barriers ensure the imperfectly competitive nature of these markets. The Cournot model of imperfect competition emphasizes quantity adjustments by a few firms and can reflect the long-term implications of international aviation competition. Kreps and 
Scheinkman (1983) show that Cournot can apply to two-stage competition where firms first set quantity and then compete via prices. Cason (1994) notes that airline industry competition is quite similar with firms first setting quantity via quarterly schedules and then competing via prices to fill seats. Even more importantly, a number of scholars (Brander \& Zhang, 1993, 1990; Oum, Zhang \& Zhang, 1993; Weisman, 1990) have empirically supported that Cournot models best reflect actual airline competition.

Third, establishing hub-and-spoke networks is one means by which airlines improve efficiency. Airline networks take advantage of density economies (Caves et al., 1984), as average costs decrease significantly on a route and in a network with increased passenger numbers; i.e., airlines exhibit substantial density economies. Integrating routes into a network brings up the issue of scope economies, which are sometimes credited with explaining the rise of hub-and-spoke networks (Weisman, 1990). Economies of scope generally refer to the production of two goods or services being managed more efficiently by one firm than by two firms (Panzar \& Willig, 1981). If one airline more efficiently provides service in two citypair markets than could two airlines, then scope economies are indicated. For instance, by consolidating a domestic service (e.g., L.A. to N.Y.) and matching it with an international service (e.g., N.Y. to London) an airline increases the number of passengers on each leg and reduces the average cost per passenger via density economies. Accordingly, the matching of different city-pair markets into a network brings about cost reductions; thus, economies from hub-and-spoke networks are often rightly referred to as scope economies (Besanko et al., 2000). This broader scope-economies-type conceptualization of airline economies becomes important in the modeling section; for this reason and for convenience, the economies generated by airline networks will sometimes be referred to as scope-economies or networkeconomies in this work. It is important to underscore, however, that these economies are founded on the existence of density economies--the matching and dominance of different airline routes promotes greater traffic density and increased capital asset utilization. 
The discussion above of the three necessary conditions (segmentation of international and domestic markets, imperfectly competitive markets, and firm economies) highlights how domestic airline mergers may improve international competitive performance; yet, here I draw out the specifics by which domestic airline mergers translate into international competitive outcomes. In particular, two causal paths are identified as connecting domestic airline mergers with improved international competitiveness: 1) a network-expansion effect; 2) a network-consolidation effect.

The basic causal-thrust behind the network-expansion effect is that domestic airline mergers which enhance domestic networks lead to improved international performance. The intuition behind the network-expansion effect is as follows: First, domestic airline mergers generally increase the size of domestic networks as the acquired firm's domestic network will augment the size of the acquiring firm’s domestic network. Second, larger domestic networks generate more passenger traffic for international route operations (drawing passengers from additional cities and passengers from competing home and foreign nation airlines) that translates into increased efficiency on the international operations via density economies. Third, airlines with more-efficient international operations earn greater traffic and profits in imperfectly competitive international markets. Accordingly, this first causal-flow between domestic mergers and international competitive performance can be summed up as follows: Domestic-Mergers $\rightarrow \wedge$ Domestic-Networks $\rightarrow \wedge$ International-Operation-Efficiency $\rightarrow \wedge$ International-Market-Performance

The basic causal-thrust behind the network-consolidation effect is that domestic airline mergers which reduce competition in domestic routes lead to improved international performance. The intuition behind the network-consolidation effect is as follows: First, domestic airline mergers that eliminate domestic competition generally result in acquiring firms enhancing their dominance of domestic routes and markets. Second, airlines that face less domestic competition and dominate domestic routes can increase domestic operational 
efficiency (an input into international service) by taking advantage of density economies. Third, airlines with more efficient domestic operations (i.e., more efficient international service that employs these domestic operations) earn greater traffic and profits in imperfectly competitive international markets. Accordingly, this second causal-flow between domestic mergers and international competitive performance can be summed up as follows: Domestic-Mergers $\rightarrow \wedge$ Domestic-Market-Dominance $\rightarrow \wedge$ Domestic-Operation-Efficiency $\rightarrow$ $\wedge$ International-Market-Performance

It should be noted that the above dynamics do not represent the full-set of causal paths by which domestic airline mergers translate into international competitive outcomes. Domestic airline mergers may also generate international competitive gains via the demandside in a complementary manner to the supply-side argument espoused above. For instance, airline mergers that expand the set of domestic destinations for frequent-flyer-award redemption essentially alter a particular airline’s demand curve for international service as the 'miles' earned by such service become more valuable. Further, demand-side peculiarities (e.g., consumer loyalty to airline or national brands) may dampen the impact of efficiencyenhancing mergers on international market outcomes. ${ }^{3}$ Despite the existence of potential demand-side factors, this analysis — akin to the IO literature on domestic airline mergersfocuses on the supply-side implications of airline mergers on international competitiveness.

\section{A COURNOT MODEL OF INTERNATIONAL AIRLINE COMPETITION}

The previous section attempts to set a thorough theoretical background by discussing the critical conditions for the main contention to hold and two causal paths by which domestic airline mergers translate into international competitive gains. This section takes a more formal approach by presenting a simple model that captures the essentials of airline competition, illustrates the network-expansion and network-consolidation incentives behind 
domestic mergers, and formally yields propositions for empirical testing. The aim is to establish a complete theoretical foundation with both analytical richness and formal precision.

The Cournot model set out below owes its domestic-international approach to Brander and Spencer (1987) and draws strongly for its aviation applicability from Weisman (1990). The cost function formulation underpins the model by creating the different market equilibrium outcomes. The total cost function takes the form:

$\mathrm{TC}=\mathrm{c} \sum \mathrm{X}_{\mathrm{i}}-\mathrm{s} * \mathrm{X}_{1} * \mathrm{X}_{2} \ldots . . * \mathrm{X}_{\mathrm{n}}$

Where $\mathrm{X}$ denotes quantity (passengers served in a city-pair market), $\mathrm{i}$ is an index of the number of routes in the network $(i=1, \ldots, N)$, and $s$ is a scope coefficient (where $s>0$ ) that broadly captures the efficiency effect of matching routes (Weisman, 1990). ${ }^{4}$ Constant average costs $\left(c^{\prime}=0\right)$ are assumed; hence, neither scale nor density economies are specified.

The omission of scale economies is in line with previous research (Caves, 1962; Douglas \& Miller, 1974; Keeler, 1978; White, 1979; Caves et al., 1984), but as already noted density economies are crucial to hub-and-spoke network economies. Instead of stipulating declining average costs, this model broadly captures network efficiency with the multiplicative term at the end of the cost function--the multiplicative term can be considered the cost savings of integrating routes within a network. It should be noted that scholars (e.g., Brueckner and Spiller, 1991, 1994; Brueckner et. al., 1992; Oum, Park \& Zhang, 1996) have modeled airline competition with greater specification of density economies by stipulating decreasing average costs with more passengers in a route. The broad approach to modeling network-economies adopted here accordingly abstracts over the fact that larger networks

\footnotetext{
${ }^{3}$ See Yoo \& Ashford (1997) for a treatment of the propensity for consumers to prefer national brands. See also Brueckner \& Whalen (2000) for a model of airline competition where consumers have brand loyalty.

${ }^{4}$ One could consider a merger scenario where $s<0$ (i.e., mergers involve diseconomies of scope). While the literature in Industrial Organization and Finance Economics suggests that many mergers do involve efficiencylosses, the assumption here is that airline mergers are generally efficiency enhancing due to the regulated history of aviation (which precluded the search for purely efficient operational systems) and the importance of density economies.
} 
improve efficiency because they facilitate the employment of density economies. Note that other scholars (e.g., Shy, 2001) also take a broad approach to representing network economies. Moreover, the competitive implications of the more-specified models and the broader approach to capturing network efficiencies employed here are similar: airlines with larger networks and less competition on market segments have lower costs and compete more effectively.

Three cases are presented to sharpen the analysis: Case A examines international duopoly competition without the presence of domestic networks; Case B examines international duopoly competition where one competitor has a domestic feed flight (a network) but faces a domestic competitor; Case C examines international duopoly competition where one competitor monopolizes the domestic route. The cases generate two propositions that exhibit the network-expansion and network-consolidation effects that underpin the main contention.

\section{Case A: International Competition Without Domestic Network Feed *** Place Figure 1 Near Here ***}

This first scenario (illustrated in figure 1) has firms A and B competing in the international market (market \#1) between points NY and UK, and firms C \& D competing in the domestic market (market \#2) between points LA and NY. Firms have no matching flights and reap no scope economies; hence, the cost functions are simple in this case, as $\mathrm{s}=0$ when no matching flights exist. Further, suppose that symmetrical inverse demand functions can be written as follows:

$\mathrm{P}_{1}=\mathrm{a}-\mathrm{b}\left(\mathrm{X}_{\mathrm{A}, 1}+\mathrm{X}_{\mathrm{B}, 1}\right)$

$\mathrm{P}_{2}=\mathrm{a}-\mathrm{b}\left(\mathrm{X}_{\mathrm{C}, 2}+\mathrm{X}_{\mathrm{D}, 2}\right)$ 
where a represents the intercept and b the slope of the linear inverse demand function. Solving the familiar Cournot duopoly-competition outlined above leads to the following solution equations:

$\mathrm{X}_{\mathrm{A}, 1}^{*}=\mathrm{X}_{\mathrm{B}, 1}^{*}=\mathrm{X}_{\mathrm{C}, 2}^{*}=\mathrm{X}_{\mathrm{D}, 2}^{*}=(\mathrm{a}-\mathrm{c}) / 3 \mathrm{~b}$

$\Pi_{\mathrm{A}}^{*}=\Pi_{\mathrm{B}}^{*}=\Pi_{\mathrm{C}}^{*}=\Pi_{\mathrm{D}}^{*}=(\mathrm{a}-\mathrm{c})^{2} / 9 \mathrm{~b}$.

Firms split the market output and profits in both the domestic and international markets in this standard solution concept.

This simplest of cases acts as a useful benchmark for comparison with the next two cases; thus, it behooves us now to set some restrictions on the model parameters in order to only make economically meaningful comparisons. First, we will assume throughout that average costs are reasonable (i.e., a $>$ c) — which simply ensures that firms have positive outputs and profits. Second, we will assume throughout that the demand curve slope is greater than the scope coefficient (i.e., b>s)—which simply ensures that the scope economies are not so great that the market equilibrium is beyond where the market demand curve lies above the supply curve. These conditions hold for the comparisons that follow.

\section{Case B: International Competition With Domestic Network Feed \& Competition *** Place Figure 2 Near Here}

The second scenario has firms A and B again competing in the international market (market \#1) between points NY and UK (illustrated in figure 2). However, firm A replaces firm D—i.e., firm D is acquired—in the domestic market between points LA and NY (market \#2) and competes against firm C. While firms B \& C have simple cost functions, firm A matches flights and takes advantage of scope economies—-firm A's cost function takes the form:

$\mathrm{TC}(\mathrm{A})=\mathrm{c}\left(\mathrm{X}_{\mathrm{A}, 1}+\mathrm{X}_{\mathrm{A}, 2}\right)-\mathrm{s} \mathrm{X}_{\mathrm{A}, 1} \mathrm{X}_{\mathrm{A}, 2} \cdot$ 
Again, assume identical demand functions in markets \#1 and \#2; i.e., equations a.1 and a. 2 are still the set of inverse demand functions. Not allowing a third inverse demand function to represent the LA - UK market is somewhat artificial; though, it does correspond to the interlining-era that dominated prior to the integration of domestic with international routes. The benefit of making such a simplifying assumption — that consumers are allowed to purchase flight segments in bundled and unbundled forms—resides with keeping things analytically and computationally tractable by focusing on the supply-side implications of route integration and disregarding any demand-side integration implications. More importantly, the general point being advanced here would also emerge from a more analytically complex treatment of airline competition in terms of both the demand and supply functions. For example, Brueckner and Whalen’s (2000) set-up of an airline-alliance competing with two non-aligned competitors is quite similar to the case here; yet, their morespecific modeling of the demand and supply functions yields solution outcomes parallel to those here.

The solution equations yield then symmetrical results for equilibrium market outputs: $\mathrm{X}_{\mathrm{A}, 1}^{*}=\mathrm{X}_{\mathrm{A}, 2}^{*}=(\mathrm{a}-\mathrm{c}) /(3 \mathrm{~b}-2 \mathrm{~s})$

$\mathrm{X}_{\mathrm{B}, 1}^{*}=\mathrm{X}_{\mathrm{C}, 2}^{*}=(\mathrm{a}-\mathrm{c})(\mathrm{b}-\mathrm{s}) / \mathrm{b}(3 \mathrm{~b}-2 \mathrm{~s})$.

Firm A has a larger output than both its competitors in markets \#1 and \#2. It can correspondingly be shown that firm A earns greater profits in both markets compared to its competitors. Firm A's total profit is:

$\Pi_{\mathrm{A}}^{*}=(2 \mathrm{~b}-3 \mathrm{~s})(\mathrm{a}-\mathrm{c})^{2} /(3 \mathrm{~b}-2 \mathrm{~s})^{2}$.

Matching flights enables firm A to be the dominant player in both the international and domestic markets. Compared to Case A, where firm A competed against firm B without the aid of domestic feed, firm A's international market output and profits have risen. It can be shown that firm A's international output (market \#1) has risen with the addition of a domestic route (market \#2), as the right hand side of equation (b.2) is larger than the right hand side of 
equation (a.3). It can also be shown that firm A’s international market profit has risen compared to Case A when it had no domestic routes. One half of the right hand side of equation (b.4) gives the profits earned by firm A in the international market (market \#1); and this is larger than the international profits without domestic feed (equation: a.4). The model illustrates how the presence of domestic feed can improve the competitive position of an international carrier, as summarized in the following proposition:

Proposition 1: The matching of domestic routes with an international routepotentially via a merger that increases domestic-network size-enhances an airline's share of the traffic and profits in the international market.

\section{Case C: International Competition With Domestic Network Feed \& Monopolization *** Place Figure 3 Near Here $* * *$}

The third scenario (illustrated by figure 3) has firms A and B again competing in the international market (market \#1) between points NY and UK. In this scenario, however, firm A no longer faces domestic competition: e.g., firm A has acquired firm C. Both cost functions and the market \#1 inverse demand function remain identical to Case B; however, the inverse demand function for market \#2 now reflects firm A’s monopoly position. Solving for the output equilibria we obtain:

$$
\begin{aligned}
& \mathrm{X}_{\mathrm{A}, 1}^{*}=(\mathrm{a}-\mathrm{c})(\mathrm{b}+\mathrm{s}) /\left(3 \mathrm{~b}^{2}-\mathrm{s}^{2}\right) \\
& \mathrm{X}_{\mathrm{A}, 2}^{*}=(\mathrm{a}-\mathrm{c})(3 \mathrm{~b}+\mathrm{s}) / 2\left(3 \mathrm{~b}^{2}-\mathrm{s}^{2}\right) \\
& \mathrm{X}_{\mathrm{B}, 1}^{*}=(\mathrm{a}-\mathrm{c})(2 \mathrm{~b}+\mathrm{s})(\mathrm{b}-\mathrm{s}) / 2 \mathrm{~b}\left(3 \mathrm{~b}^{2}-\mathrm{s}^{2}\right) .
\end{aligned}
$$

Unsurprisingly, we observe that Firm A’s international market output dominates firm B’s (c.1 > c.3). More importantly, firm A's international output has increased compared to the Case B scenario; the right hand side of (c.1) is greater than that of (b.2). It can correspondingly be shown that Firm A's international profit increases in this domestic monopolization case compared to when Firm A had a domestic competitor (Case B). These 
results suggest international competitive gains for airlines that eliminate domestic competition and allow the generation of a simple proposition:

Proposition 2: The domination of domestic routes—potentially via a merger that reduces domestic competition-enhances an airline's share of the traffic and profits in the international market.

The simple model of international airline competition, with its imperfectly competitive nature and role for network economies, illustrates the potential international competitive gains for airlines engaging in domestic mergers that enhance (increase the size) and consolidate (reduce route competition) domestic network structures. Case A demonstrated international competition without domestic feeder routes and had the two competitors split market output and profits evenly. Case B highlighted the proposed networkexpansion effect: an additional domestic feeder route-potentially via a domestic merger or acquisition-increases an airline’s international market output and profits (Proposition 1). Case C highlighted the proposed network-consolidation effect: eliminating domestic competitors—potentially via a domestic merger or acquisition—may further increase an airline’s international market output and profits (Proposition 2). In sum, propositions 1 and 2 underscore that airlines improve international competitiveness by enhancing domestic networks and reducing domestic competition—both byproducts of domestic merger activity.

\section{EMPIRICAL TESTS AND RESULTS}

The analysis of the impact of domestic mergers on international competitive performance involves an estimation procedure based on the features of both panel data and structural equations models. The strength of a structural equations approach resides in representing multiple relationships among a set of variables_-in this particular case, the approach helps examine the causal paths by which domestic airline mergers impact international competitive outcomes. The strength of panel data methods resides in enhancing 
causal inferences when data combine both cross-sectional and time-series qualities - in this particular case, the approach helps control for airline-route, airline country-of-origin and time-specific effects. Moreover, the empirical tests presented here examine whether domestic airline mergers improve international competitive position via two causal paths: first, via enhanced domestic networks (in line with proposition 1); second, via increased domestic dominance (in line with proposition 2).

\section{Data Set Description}

The data for the empirical tests primarily derive from the International Civil Aviation Organization’s (ICAO) ‘Traffic by Flight Stage’ (TFS) series—a series that measures airline segment traffic between international city-pairs. In addition, data from ICAO’s 'Traffic' series complements the TFS data by capturing the broader characteristics of international airlines. Unfortunately, international-segment-traffic data include passengers flying between two international city-pairs that have origins and/or destinations beyond the segment citypairs. Consequently, the more a particular international city-pair segment involves a gateway to origins and/or destinations beyond the two city-pairs, the more the data may involve measurement error. While general opinion holds that origin-and-destination (O\&D) data best reflect airline industry competition, such first-best data do not exist on a cross-national basis for the period of study. Simply put, the TFS international city-pair market segment data represent the best available alternative for studying the international markets between multiple nations over the $1984-1992$ period. $^{5}$

Consider the following in order to get an intuitive feel for the nature of the panel data employed for estimations. The data cover the international performance of forty-four airlines

\footnotetext{
${ }^{5}$ Unreported tests based on data that aggregate international city-pair market segments into country-pair market segments (where the hubbing bias will be less pronounced) provide qualitatively similar results and support the segment-based tests reflecting O\&D competition. Note also that non-US airlines do not often have multiple home-nation hubs or gateways; accordingly, international segment data will be less subject to measurement error for those observations.
} 
from twenty nations over the $1984-1992$ period. ${ }^{6}$ The data involve 10,161 observations where each observation consists of a specific airline's yearly performance in a specific international city-pair market segment; i.e., observations are at the airline/route/year level-of-analysis. For instance, the performance by British Airways in the London-Montreal market-segment is one panel (airline-route) that consists of up to nine observations over the 1984-1992 period.

Further, the data contain a total of 2,021 airline-routes. Reflect on the number of observations $(10,161)$, the number of airline-routes $(2,021)$ and the number of years $(9)$; and the unbalanced nature of panels becomes obvious - no surprise in light of the fact that airlines tend to enter and exit markets frequently. Note that airlines must compete in a specific market to be included as an observation: i.e., no zero market-performance data points were included. $^{7}$

A number of variables were generated from the TFS and TRF data series. While these variables will be employed in the subsequent section on 'Estimation Strategy', it behooves us here to set out and define the variables. The system of equations will include three endogenous variables: an airline’s domestic network size; an airline’s domestic market dominance; an airline’s market-share in the international market segment.

Testing proposition 1-mergers that enhance domestic networks improve international competitive performance-requires a measure of domestic network size. An airline’s number of annual domestic departures acts as the measure of domestic network size (referred to as Domestic-Network). While the number of domestic cities-served is often employed to measure network size (e.g., Caves et al., 1984), domestic departures roughly

\footnotetext{
${ }^{6}$ First, see table 2 for a listing of the 44 airlines. Second, the 20 nations--Argentina, Australia, Brazil, Canada, Chile, Finland, France, Germany, Greece, Ireland, Italy, Japan, Mexico, Netherlands, New Zealand, Portugal, Spain, Switzerland, United Kingdom, and the United States - are referred to as the twenty advanced aviation nations. The OECD nations and the four more developed Latin American nations were initially selected, but a few OECD nations were dropped due to insufficient data.

${ }^{7}$ Further, any observations where the airline monopolized or dominated the international market segment (i.e., market-share $>90 \%$ ) were dropped. Further, any observations where the airline was playing a marginal or fringe role (market-share $<1 \%$ ) in the international market segment were also dropped.
} 
capture domestic network size by representing the large set of domestic flights on which an airline can draw upon in order to establish an efficient domestic network.

Testing proposition 2-mergers that reduce domestic competition improve international competitive performance-requires a measure of domestic market dominance. Taking an airlines share of total domestic passengers and dividing by home-nation domestic Herfindahl Index (HI), I created a measure that captures the degree to which an airline dominates its domestic market (referred to as Domestic-Dominance). This variable reflects whether the airline's domestic market presence (as measured by share of domestic passengers) is relatively large or small compared to all domestic competitors (as measured by domestic HI). For example, imagine an airline with a 25\% share of the domestic market: this market-share would be proportionate (Domestic-Dominance $=100)$ if the domestic market consisted of 4 equal competitors (HI=.25); relatively large (Domestic-Dominance $>100)$ if the domestic market was more competitive (i.e., $\mathrm{HI}<.25$ ); and relatively small (DomesticDominance < 100) if the market was less competitive (i.e., HI > .25).

Testing both propositions’ 1 and 2 requires a measure of an airline’s competitive performance in international markets. An airline’s annual share of the revenue passengers in an international market segment acts as the measure of airline competitive performance (referred to as International-Market-Share). International market-shares are assumed then to roughly correlate with international market-profitability: the ultimate goal of airlines. Yet the realm of strategic competition supports a number of market outcomes, as it is difficult to predict competitor actions in a strategic environment. Accordingly, a one-to-one relationship between market-share and profitability will not be found in practice. Underscoring the difficulties of making a pure link between market-share and profits, Windle and Dresner (1992) find total-factor-productivity (TFP) to not consistently/robustly correlate with airline profitability; though, they do find change in TFP to partly correlate with change in profits. Nevertheless, Kurtz and Rhoades (1992) find evidence supporting a general link between 
profits and market share; moreover, Adrangi et al. (1989) and Antoniou (1992) empirically support a link between airline-profits and market-shares. Accordingly, we move forward with market-share as a measure of airline performance, but are mindful of its deficiencies.

Beyond the three endogenous variables, a number of additional variables will be helpful in setting out the system of equations: a measure of domestic merger activity; the number of home and foreign competitors on an international city-pair market-segment; an airline's international network size. Table 1 provides concise descriptions for all the variables discussed above and below.

\section{*** Place Table 1 Near Here ***}

Testing both proposition $1 \& 2$ requires a measure of actual merger activity. Using a number of secondary sources, fifteen airlines were identified over the 1984-1992 period as engaging in domestic airline mergers. ${ }^{8}$ This data allowed the creation of a merger dummy variable (referred to as Merger) that was coded 1 in all the years subsequent to the year of an airline’s first domestic merger within the nine year period.

The list of variables includes two measures of the number of competitors in a particular international market. The number of home-based and foreign-based competitors faced by an airline in a specific international city-pair market segment (referred to as HomeCompetitors and Foreign-Competitors respectively) captures simple but important drivers of actual airline market shares. Note that since the observations are arranged on an airline-routeyear basis, an observation for an airline that is the sole national carrier on a duopolistic route will have Home-Competitors=0 and Foreign-Competitors=1.

\footnotetext{
${ }^{8}$ Meyer \& Strong, 1992; Pustay, 1992; Oum, Taylor \& Zhang, 1993; self-histories on the official websites of airlines; and additional websites covering the world airline industry: http://www.flash.net/ airline/tree.html; http://airlines.afriqonline.com/airlines/index.html; http://en.wikipedia.org/wiki/Main_Page -- were all sources used to identify the domestic merger behavior of the 44 airlines in the sample. Two of the above sources were required to identify the completion date of an airline's domestic merger. Note also that non-domestic-mergers (e.g., the acquisition of PanAm's international operations by United and Delta Airlines) are not domestic airline mergers and are accordingly not identified as domestic airline mergers here. See Table 2 for a list of the 44 airlines in this study and a list of the years on which they made their first domestic airline merger and/or acquisition.
} 
Lastly, the list of variables includes a measure of an airline’s international network size that complements the domestic network variable. Accordingly, an airline's number of annual international departures acts as the measure of international network size (referred to as International-Network). Table 2 reports descriptive statistics that include the year when sampled airlines engage in their first domestic merger, the number of observations by airline, and the means for variables employed.

*** Place Table 2 Near Here ***

\section{Estimation Strategy}

Recall that domestic mergers are hypothesized to positively influence international competitive performance via two causal paths: first, via enhanced domestic networks (in line with proposition 1); second, via increased domestic dominance (in line with proposition 2). Accordingly, the intuition that large domestic networks and the elimination of domestic competitors allow an airline to take advantage of network economies and improve international competitive performance resides behind the empirical tests. If larger domestic networks and domestic market dominance improve an airline’s international competitive position, then it behooves airlines to seek domestic mergers that both expand and consolidate domestic network structures for international competitive rationales as well as domestic competitive rationales.

The first causal path (proposition 1) can be operationally reduced for empirical estimation to the following causal links: domestic airline mergers increase the size of domestic networks, and airlines with larger domestic networks garner larger market-shares in imperfectly competitive international markets. Similarly, the second causal path (proposition 2) can be operationally reduced for empirical estimation to the following causal links: domestic airline mergers reduce domestic competition, and airlines that dominate domestic markets garner larger market-shares in imperfectly competitive international markets. 
Accordingly, the empirically-operationalized causal paths implied by the two propositions can be illustrated as follows:

Proposition 1-the Network-Expansion Effect:

Mergers $\rightarrow \wedge$ Domestic-Networks $\rightarrow \wedge$ International-Market-Share

(3)

Proposition 2-the Network-Consolidation Effect:

Mergers $\rightarrow \wedge$ Domestic-Dominance $\rightarrow \wedge$ International-Market-Share

It is important to point out that the above causal-flows both skip one step in the causal process outlined earlier: namely, the empirically-operationalized proposition 1 neglects the concept of international efficiency which connects larger domestic networks with improved international market-shares (see causal-flow 1); and the empirically-operationalized proposition 2 neglects the concept of domestic efficiency which connects domestic dominance with improved international market-shares (see causal-flow 2). This simplification of the causal paths is taken in part to keep the structural equations modeling tractable; but more importantly, I lack consistent data on both the international and domestic efficiency of airlines. ${ }^{9}$

In order to empirically test the two propositions, I generate a recursive econometric specification (RES) that consists of three structural equations with three endogenous variables:

- Domestic-Network $_{\mathrm{it}}=\mathrm{a}_{0}+\mathrm{a}_{1}$ Merger $_{\mathrm{it}}+\mathrm{a}_{2}$ International-Network $\mathrm{it}_{\mathrm{i}-1}+\mathrm{a}_{3}$ DomesticNetwork $_{\text {it- } 1}+\alpha^{1}{ }_{\mathrm{i}}+\delta_{\mathrm{k}}^{1}+\gamma_{\mathrm{t}}^{1}+\varepsilon_{\text {it }}^{1}$

- Domestic-Dominance $_{i t}=b_{0}+b_{1}$ Merger $_{i t}+b_{2}$ Domestic-Dominance $_{i t-1}+\alpha^{2}{ }_{i}+\delta^{2}{ }_{k}+$ $\gamma_{t}^{2}+\varepsilon^{2}$ it

\footnotetext{
${ }^{9}$ A previous paper version - where international efficiency data is brought in to the estimation - partially addresses this omission and simplification. The paper is available from the author on request.
} 
- International-Market-Share ${ }_{i t}=c_{0}+c_{1}$ Domestic-Network $_{i t}+c_{2}$ Domestic-Dominance $_{i t}$

$+{ }_{j=1} \sum^{2} \mathrm{C}_{\mathrm{j}+2}$ (Home-Competitors) ${ }_{i t}^{\mathrm{j}}+{ }_{\mathrm{j}=1} \sum^{2} \mathrm{c}_{\mathrm{j}+4}$ (Foreign-Competitors) ${ }_{i \mathrm{it}}^{\mathrm{j}}+\mathrm{c}_{7}$

International-Market-Share ${ }_{\mathrm{it}-1}+\alpha^{3}{ }_{\mathrm{i}}+\delta_{\mathrm{k}}^{3}+\gamma_{\mathrm{t}}^{3}+\varepsilon^{3}{ }_{\text {it }}$

where i indexes an airline's international city-pair market segment, t indexes time, $\mathrm{j}$ allows for a convenient expression of the non-linear variables, $\mathrm{k}$ indexes an airline’s country-of-origin, $\alpha_{\mathrm{i}}$ represents the fixed panel-specific (airline-route) effect, $\delta_{\mathrm{k}}$ represents the fixed airlinecountry effect, and $\gamma_{t}$ captures the fixed period-specific effect.

The individual equations within the system take advantage of the data's panel-nature by controlling for three types of fixed effects. First, controlling for any airline-route (i.e., panel-specific) effect owing to an airline’s particular position in an individual international city-pair segment is represented by the term $\alpha_{\mathrm{i}}$. Empirically, the panel-specific effect is estimated by employing a within-transformation (Wooldridge, 2002); thus, allowing for the control of an additional fixed-effect without introducing collinearity. Second, controlling for any airline-country effect owing to an airline’s country-of-origin is represented by the term $\delta_{\mathrm{k}}$. The airline-country effect allows holding constant any non-varying effects due to national customer loyalty, national regulatory policy, or other national characteristics residing behind an airline's country-of-origin. Third, time-specific trends in international airline markets may also affect causal inferences on the explanatory variables; thus, introducing period effects can at least partially control for some of the time-specific trends. Accordingly, all of the reported regression equations within the system take advantage of the data's panel nature by controlling for fixed 'airline-route', 'airline-country' and 'period' effects.

Further, the equations within the above system present an additional econometric issue beyond the panel nature of the data: a lagged dependent variable is included as an explanatory variable in all three equations. The inclusion of lagged dependent variables means the individual equations can be considered static-score models (Finkel, 1995). With 
static-score models, the coefficient estimates for explanatory variables should be interpreted as indicating change in the dependent variable. Or put differently, causal variable coefficient estimates measure the short-term, not long-term, effects on the dependent variable. ${ }^{10}$

Equation RES.1 represents the first-link in the recursive system outlined above, as it attempts to elicit the impact of actual domestic airline mergers on the size of an airline's domestic network: the basis for the network-expansion effect. Beyond the dummy variable (Merger) that captures the impact of domestic airline mergers on domestic networks, the airlines lagged international network (International-Network) is also included as an explanatory variable in order to make better causal inferences on the merger dummy variable. Recall that the lagged dependent-variable is also included in the regression; thus, the coefficient estimates for the other explanatory variables can be interpreted as indicating change in the dependent variable (Domestic-Network). Accordingly - and despite potential under-specification - the nature of this first equation should lead to modest interpretations of merger-effects on domestic networks, as the merger dummy variable will simply capture the average post-merger change per year in domestic network size and not the full compounding effect of the merger on domestic network size.

Equation RES.2 represents a second first-link in the recursive system outlined above, as it attempts to elicit the impact of actual domestic mergers on an airline’s dominance of the home domestic market: the basis for the network-consolidation effect. In addition to the merger dummy variable (Merger), the lagged dependent variable is again included as a regressor. Hence, the merger dummy variable’s coefficient estimate can be interpreted as indicating change in the dependent variable (Domestic-Dominance). Further, this equation should also lead to relatively modest interpretations of the merger-effect on domestic

\footnotetext{
${ }^{10}$ One danger with introducing a lagged-dependent variable as a regressor is that it may be related to the residual-term; thus, leading to biased coefficient estimates. While diagnostics suggest no overtly significant relationship, Appendix A reports the same system of equations that will be estimated in Table 3 except for the exclusion of all lagged-dependent variables. The results in Appendix A actually support Propositions' 1 \& 2 more fully than the main results in Table 3 employing a staticscore model; thus, further reducing concerns of biased coefficient estimates.
} 
dominance, as the dummy variable will again simply capture the average post-merger change per year in domestic market dominance for merging airlines.

Equation RES.3 takes the final step by considering the impact of both domesticnetwork and domestic-dominance on the international market shares of airlines. Beyond the two principal variables (Domestic-Networks \& Domestic-Dominance) and the lagged dependent variable (International-Market-Share ${ }_{t-1}$ ), the list of explanatory variables for this equation includes the number of home and foreign competitors faced by an airline in a specific international city-pair segment (Home-Competitors and Foreign-Competitors respectively). While the equation is assumed to be linear, the competitor variables may be non-linear in functional form (i.e., subject to increasing or decreasing returns). Potential nonlinearity in the competitor variables is particularly important to capture, as these variables are charged with controlling for both the nature of the imperfectly competitive environment and the source (home or foreign) of actual competition. If the competitor variables capture as much variation in the dependent variable as possible, then we can interpret the coefficient estimates of the main explanatory variables with more precision: i.e., the Domestic-Network and Domestic-Dominance variables will then account for any deviation between competitorprojected international market-share and actual market share. The inclusion of the squaredterms for the competitor variables passed F-tests for the incremental contribution of an added explanatory variable (Gujarati, 1988).

\section{Estimation Results \& Interpretation}

The recursive nature of the system of equations allows unbiased estimation via an ordinary-least-squares (OLS) process: in effect, Domestic-Network and DomesticDominance can be considered pre-determined variables in so far as International-MarketShare is concerned (Maddala, 1992). Nevertheless, estimation efficiency of a nonsimultaneous system of equations can be improved if cross-equation correlations are taken 
into account; hence, calling for estimation via a seemingly-unrelated-regression (SUR) process - i.e., a Zellner (1962) regression. Further, it behooves us to ensure that DomesticNetwork and Domestic-Dominance can be effectively treated as exogenous regressors in equation RES.3; thus, calling for a two-stage-least-squares (2SLS) and three-stage-leastsquares (3SLS) estimation process. The two-stage-least-squares process replaces the potentially dependent regressors with predicted values to ensure independence with the stochastic disturbance term. The three-stage-least-squares process involves both a 2SLS-like purification of potentially dependent regressors and a SUR-like accounting of cross-equation correlations. Table 3 accordingly presents the recursive system-of-equations estimated via the OLS, SUR, 2SLS and 3SLS processes to ensure consistency and robustness of results across specifications. ${ }^{11}$

\section{*** Place Table 3 Near Here ***}

The four estimation procedures generate statistically significant results that conform to expectation: the system-weighted R-squares - generated for the SUR and 3SLS procedures - are .52; and all the coefficient estimates for the principal explanatory variables have the expected sign and are significant at the $1 \%$ or $5 \%$ level. While the estimation results conform across models, the 3SLS (where both endogenous regressors are instrumented and crossequation correlations factored) estimation procedure is a bit more ambitious than the rest, and appears to yield slightly more modest coefficient-estimate interpretations. For this reason, and for brevity, the following analysis concentrates on the 3SLS estimation procedure while discussing the results equation by equation.

Equation RES.1 (the Domestic-Network equation) estimates a fixed-and-period effects specification that yields a single-equation R-square of .64 via the 2SLS and OLS

\footnotetext{
${ }^{11}$ The following variables were employed as instruments for the 2SLS \& 3SLS estimation processes: Merger, HomeCompetitors, Home-Competitors ${ }^{2}$, Foreign-Competitors, Foreign-Competitors ${ }^{2}$, lagged International-Network, lagged Domestic-Network, lagged Domestic-Dominance, lagged International-Load-Factor (percentage of an airline's seats in an international market segment filled by revenue passengers), lagged International-Aircraft-Size (average annual size number of seats - of aircraft employed by an airline on an international market segment), lagged International-Market-Size
} 
procedures; hence, the equation appears relatively well specified. Further—and more importantly_all the coefficient estimates meet expectation and are significant at the $1 \%$ level. The coefficient estimates for lagged Domestic-Network (.781) and lagged International-Network (.098) are positive and significant; hence, airlines with larger domestic and international networks tend in the near-future to have larger domestic networks. In particular, the relatively large coefficient estimate for the lagged dependent variable indicates a relatively slow adjustment pace: where $\lambda$ reflects adjustment pace $\left(\lambda=1-\alpha_{3}\right)$ and thus equals 0.219 on average (Martin, 1979). Simply put, domestic networks are not created anew each year. The variable of principal interest is the merger dummy variable: the coefficient estimate for Merger $(10,337)$ implies that airlines engaging in domestic mergers experience an average yearly increase in the size of their domestic network of some 10,377 departures per year ( $9 \%$ of the sample’s average ‘domestic network size’—see Table 2). Accordingly, domestic airline mergers tend to generate larger domestic networks.

Equation RES.2 (the Domestic-Dominance equation) estimates a fixed-and-period effects specification that yields a single-equation R-square of .43 via the 2SLS and OLS procedures; hence, the equation appears relatively well specified. Further-and more importantly_all the coefficient estimates meet expectation and are significant at the $1 \%$ level. The coefficient estimate for lagged Domestic-Dominance (.646) suggests that pastlevels of domestic market dominance substantially impact future levels of domestic dominance; again, the adjustment pace is relatively slow. The variable of principal interest is the merger dummy variable: the coefficient estimate for Merger (2.04) indicates that airlines engaging in domestic mergers experience a post-merger increase in domestic market dominance.

Regression RES.3 estimates a fixed-and-period effects specification that yields a single-equation R-square of .33 via the 2SLS and OLS procedures; hence, the equation 
appears relatively well specified. Further-and more importantly—all the coefficient estimates meet expectation and are significant at the 1\% level (except for the DomesticDominance coefficient estimate at the 5\% level). The coefficient estimate for DomesticNetwork (.000024) implies that an airline increasing annual domestic departures by 100,000 increases international market shares by 2.4 percentage points on average. The coefficient estimate for Domestic-Dominance (.032) implies that airlines engaging in domestic mergers that increase the domestic dominance index by 31.25 points increase international market shares by 1.0 percentage point on average. The coefficient estimate for Home-Competitors indicates declining market shares with increased counts of home competitors on a route; yet, the squared term indicates a moderated decline at higher levels of home competition. Similarly, the coefficient estimate for Foreign-Competitors indicates declining market shares with increased counts of foreign competitors; though, the squared term again indicates a moderated decline at higher levels of foreign competition. Lastly, the coefficient-estimate for the lagged dependent variable (.27) indicates a relatively rapid-adjustment pace; accordingly, international market shares are far more dynamic than domestic network size and domestic market dominance. Since equation RES.3 represents the core of the structural equations testing, it behooves us to discuss some coefficient estimates (namely Domestic-Network, Domestic-Dominance, and the competitor variables) with a bit more detail.

First, the empirical results indicate statistical significance for the domestic network size variable; yet, the economic significance of the coefficient estimates is far more important than statistical significance. Consider the following actual merger-induced changes to domestic network size to better understand the economic significance of domestic airline networks. Northwest increased its domestic network size by 323,000 annual domestic departures when it acquired Republic Airlines; thus, the coefficient estimate suggests that Northwest increased its post-merger international market performance by 7.8 percentage 
points. Similar use of the Domestic-Network coefficient estimate allows approximating the international market gains for other domestic-airline mergers: the Delta/Western airline merger translates into international city-pair market gains of 4.4 percentage points; the series of mergers that led to Canadian Airlines translate into a 2 percentage point increase; and the British-Airways/British-Caledonia and Air-France/Air-Inter mergers translate into gains of around 0.5 percentage points.

Second, the empirical results indicate statistical significance for the domesticdominance variable; yet, it again bears analyzing the economic significance. Consider the following actual merger-induced changes to the domestic market dominance index to better understand economic significance. British Airways increased market dominance by 30.5 points when it acquired British Caledonia; thus, the coefficient estimate suggests that BA increased its post-merger international market performance by almost 1 percentage point. Northwest and Continental Airlines both increased domestic market dominance by around 47 points; thus, suggesting that both airlines experienced a 1.5 percentage point increase in international market shares on average. Finally, the series of mergers that led to Canadian Airlines translate into a 1.7 percentage point increase due to enhanced domestic market dominance.

Third, the results concerning the competitor variables is worth consideration as the impact of foreign-competitors on an airline's international-market-share appears to dominate the impact of home-competitors. While this observation is born out, the impact is not as significant as a first glance at the coefficient estimates might suggest. Recall that the typical airline-route-year observation involves a duopoly situation where Home-Competitors $=0$ and Foreign-Competitors=1; hence, a good comparison of the marginal impact of an additional home or foreign competitor would take such a duopoly as a starting benchmark. Using that benchmark and taking into account the squared terms allows factoring the net-impact of an additional competitor on a focal airline’s international-market-share: an additional home- 
competitor leads to a 8.5 percentage point drop in market-share on average, while an additional foreign-competitor leads to a 13.5 percentage point drop in market-share on average. In short, foreign competitors appear to represent a more vigorous competitive threat than do home competitors. This may owe to the fact that national consumers prefer homenation airlines (Yoo \& Ashford, 1997); hence, an additional foreign airline has a better chance of shifting foreign consumers away from a focal airline than does an additional home airline. In line with this conjecture, comparisons of the impact of additional home and foreign competitors in situations with more than duopolistic competition indicate that the marginal impact of an additional home and foreign competitor begin to equilibrate; i.e., all those foreign-consumers who were predisposed to favor a foreign-airline have already expressed that preference.

In sum, the results above suggest that domestic airline mergers lead to improved international competitive performance via both a network-enhancement and a networkconsolidation effect. In terms of network-enhancement: domestic airline mergers lead to larger domestic networks which in turn lead to higher international-market-shares. In terms of network-consolidation: domestic airline mergers lead to more domestic market dominance which in turn leads to higher international market shares. Moreover, the results also allow factoring the indirect structural effect of domestic mergers on international-market-share in order to gather which causal path is relatively more robust. Employing the standardized coefficient estimates (see Mueller 1996 for more process details) suggests that the indirect structural effect of Merger on International-Market-Share via Domestic-Network is quadruple the indirect structural effect of Merger on International-Market-Share via Domestic-Dominance. In short, the majority of gains (80\%) from engaging in domestic mergers derive from enlarging domestic networks. 
My main contention has been that the domestic airline merger activity of the late 1980s and early 1990s had an important international dimension, as domestic mergers improve an airline's international competitive position. The domestic competitive incentives (efficiency-gains and market-power) focused on by the IO literature clearly play a significant role in determining airline merger activity; however, a complete explanation of the crossnational domestic airline merger phenomenon appears to require consideration of international incentives. International competitive gains are particularly vital in explaining the proliferation of domestic airline mergers to nations where international markets predominated and/or where domestic markets remained regulated.

The main contention that domestic airline mergers improve international competitiveness rests upon two proposed causal paths. First, a network-enhancement path which suggests that airlines with large domestic networks reap efficiency gains in international operations that translate into larger international market shares. Second, a network-consolidation path which suggests that airlines with less domestic competition reap efficiency gains in domestic operations that translate into larger international market shares. A simple Cournot model reflects the theoretical backing, generates formal propositions concerning the network-enhancement and network-consolidation effects, and establishes the logic behind the empirical tests. In short, the model formally clarifies the main contention by illustrating that mergers-which enhance domestic networks and reduce domestic competitors-generate international competitive gains.

The empirical tests employ a structural equations approach based on comprehensive panel data covering the international airline markets between twenty advanced aviation nations over the 1984-1992 period. The empirical results yield supporting evidence for the network-enhancement effect: domestic mergers lead to larger domestic networks, which in turn lead to higher international market shares. The empirical results also yield supporting evidence for the network-consolidation effect: domestic mergers lead to the dominance of 
domestic markets which in turn leads to higher international market shares. In short, the empirical results clearly support the presence of an international competitive incentive behind domestic airline mergers that enhance domestic airline networks and reduce domestic competition.

Domestic airline mergers appear to have an important international dimension; hence, completely understanding the domestic airline merger phenomenon requires analyzing both the international context and international determinants of domestic merger activity. An IB perspective can then complement the traditional IO approach to airline competition issues by widening the analytical frame to include cross-national business activity (e.g., non-US domestic airline mergers) and by prodding the discovery of cross-border interactions that affect domestic strategies and actions (e.g., international competitive incentives behind domestic mergers).

In sum, the argument here is simple but important: first, the IO and IB perspectives complement each other by helping better diagnose and analyze the motives behind the domestic airline merger phenomenon; second, the cross-national domestic airline merger phenomenon was driven by international, as well as domestic, competitive incentives.

\section{REFERENCES}

Adrangi B, Chow G, Gritta R. 1989. Market Structure, Market Share, and Profits in the Airline Industry. Journal of Transportation Research Forum 29(2): 223-227.

Antoniou A. 1992. The Factors Determining the Profitability of International Airlines: Some Econometric Results. Managerial and Decision Economics 13(6): 503-514.

Besanko D, Dranove D, Shanley M. 2000. Economics of Strategy. John Wiley \& Sons, Inc.: New York, NY.

Borenstein S. 1989. Hubs and High Fares: dominance and market power in the U.S. airline industry. Rand Journal of Economics 20(3): 344-365.

Brander JA, Spencer BJ. 1987. Tariffs and the Extraction of Foreign Monopoly Rents under Potential Entry. In International Trade: Selected Readings, Bhagwati JN (ed). MIT Press: Cambridge, MA. 
Brander JA, Zhang A. 1993. Dynamic Oligopoly Behavior in the Airline Industry. International Journal of Industrial Organization 11: 407-35.

Brander JA, Zhang A. 1990. Market Conduct in the Airline Industry: An Empirical Investigation. Rand Journal of Economics 21: 567-83.

Brueckner J, Spiller PT. 1991. Competition and mergers in airline networks. International Journal of Industrial Organization 9: 323-42.

Brueckner J, Spiller PT. 1994. Economies of Traffic Density in the Deregulated Airline Industry. Journal of Law \& Economics 37: 379-415.

Brueckner J, Dyer N, Spiller PT. 1992. Fare Determination in Airline Hub \& Spoke Networks. Rand Journal of Economics 23(3): 309-333.

Brueckner JK. 2003. International Airfares in the Age of Alliances: The Effects of Codesharing and Antitrust Immunity. The Review of Economics and Statistics 85(1): 105118.

Brueckner JK, Whalen T. 2000. The Price Effects of International Airline Alliances. Journal of Law \& Economics 43: 503-545.

Cason TN. 1994. The Strategic Value of Asymmetric Information Access for Cournot Competitors. Information Economics and Policy 6: 3-24.

Caves DW, Christensen LR, Tretheway MW. 1984. Economies of Density Versus Economies of Scale: Why trunk and local service airline costs differ. Rand Journal of Economics 15(4): 471-89.

Caves RE. 1962. Air Transport and Its Regulators: an industry study. Harvard University Press: Cambridge. MA.

Clougherty JA. 2001. Globalization and the Autonomy of Domestic Competition-Policy: An Empirical Test on the World Airline Industry. Journal of International Business Studies 32(3): 459-478.

Clougherty JA. 2002. US Domestic Airline Mergers: The Neglected International Determinants. International Journal of Industrial Organization 20(4): 557-576.

De Murias R. 1989. The Economic Regulation of International Air Transport. McFarland: Jefforson, NC.

Douglas GW, Miller JC, III. 1974. Economic Regulation of Domestic Air Transport: Theory and Policy. Brookings Institution: Washington, DC.

Finkel SE. 1995. Causal Analysis with Panel Data. Sage Publications: Thousand Oaks.

Gujarati DN. 1988. Basic Econometrics. McGraw-Hill: USA. 
Keeler TE. 1978. Domestic Trunk Airline Regulation: An Economic Evaluation. In Study on Federal Regulation. U.S. Government Printing Office: Washington, DC.

Kim EH, Singal V. 1993. Mergers and Market Power: Evidence from the Airline Industry. American Economic Review 83(3): 549-569.

Kreps D, Scheinkman J. 1983. Quantity Pre-commitment and Bertrand Competition Yield Cournot Outcomes. Bell Journal of Economics 14: 326-37.

Krugman PR. 1994['84]. Import Protection as Export Promotion: International Competition in the Presence of Oligopoly and Economies of Scale. In Imperfect Competition and International Trade, Grossman GM (ed). MIT Press: Cambridge, MA.

Kurtz RD, Rhoades SA. 1992. A Note on the Market Share-Profitability Relationship. Review of Industrial Organization 7: 39-50.

Levine M. 1987. Airline Competition in Deregulated Markets: Theory, Firm Strategy, and Public Policy. Yale Journal on Regulation 4: 393-494.

Maddala GS. 1992. Introduction to Econometrics. Macmillan Publishing Company: New York, NY.

Martin S. 1979. Advertising, concentration and profitability. Bell Journal of Economics 10: 639-647.

Meyer JR, Strong J.S. 1992. From Closed Set to Open Set Deregulation: An assessment of the U.S. Airline Industry. Logistics and Transportation Review. 28(1): 1-21.

Morrison SA, Winston C. 1987. Empirical Implications and Tests of the Contestability Hypothesis. Journal of Law \& Economics 30: 53-66.

Morrison SA, Winston C. 2000. The Remaining Role for Government Policy in the Deregulated Airline Industry. In Deregulation of Network Industries: What's Next?, Peltzman S, Winston C (eds). Brookings Institution Press: Washington DC.

Mueller RO. 1996. Basic Principles of Structural Equation Modelling. Springer Texts: Berlin, Germany.

Nehrt L, Truitt F, Wright R. 1970. International Business Research: Past, Present, and Future. Bureau of Business Research, Indiana University: Bloomington, IL.

Oum TH, Taylor AJ, Zhang A. 1993. Strategic Airline Policy in the Globalizing Airline Networks. Transportation Journal 32(April): 14-30.

Oum TH, Zhang A, Zhang Y. 1993. Inter-firm Rivalry and Firm Specific Price Elasticities in Deregulated Airline Markets. Journal of Transport Economics and Policy 27: 171-92.

Oum TH, Park J-H, Zhang A. 1996. The Effects of Airline Codesharing Agreements on Firm Conduct and International Air Fares. Journal of Transport Economics and Policy 30(2): 187-202. 
Panzar JC, Willig RD. 1981. Economies of Scope. American Economic Review 71: 268272.

Pustay MW. 1989. Liberalization of US International Aviation Policy: A Preliminary Assessment. Quarterly Review of Economics and Business 29(2): 15-26.

Pustay MW. 1992. Toward a Global Airline Industry: Prospects and Impediments. Logistics and Transportation Review 28(1): 103-128.

Ramamurti R, Sarathy R. 1997. Deregulation and Globalization of Airlines. The International Trade Journal 11(3): 389-432.

Shy O. 2001. The Economics of Network Industries. Cambridge University Press: Cambridge, MA.

U.S. General Accounting Office. 1988. Airline Competition: Fare and Service Changes at St. Louis Since the TWA-Ozark Merge. General Accounting Office: Washington DC, Report No. GAO/RCED-88-217BR.

Weisman E. 1990. Trade in Services and Imperfect Competition: Application to International Aviation. Kluwer Academic Publishers: Dordrecht, Holland.

Werden GJ, Joskow AS, Johnson RL. 1991. The Effects of Mergers on Price and Output: Two Case Studies from the Airline Industry. Managerial and Decision Economics 12: $341-$ 52.

White LJ. 1979. Economies of Scale and the Question of 'Natural Monopoly' in the Airline Industry. Journal of Air Law and Commerce 44: 545-73.

Windle R, Dresner M. 1992. Partial Productivity Measures and Total Factor Productivity in the Air Transport Industry: Limitations and Uses. Transportation Research, Part A 26a(1): 435-445.

Wooldridge JM. 2002. Econometric Analysis of Cross Section and Panel Data. The MIT Press: Cambridge, MA.

Yoo EY, Ashford N. 1997. "Choice Behaviour of Air Passengers in the Pacific Rim,” Air Transport Research Group Meeting, Vancouver, BC, Canada, June 27, 1997.

Zellner A. 1962. An Efficient Method of Estimating Seemingly Unrelated Regressions and Tests for Aggregation Bias. Journal of the American Statistical Association 57: 348-368. 
Figure 1: Case A

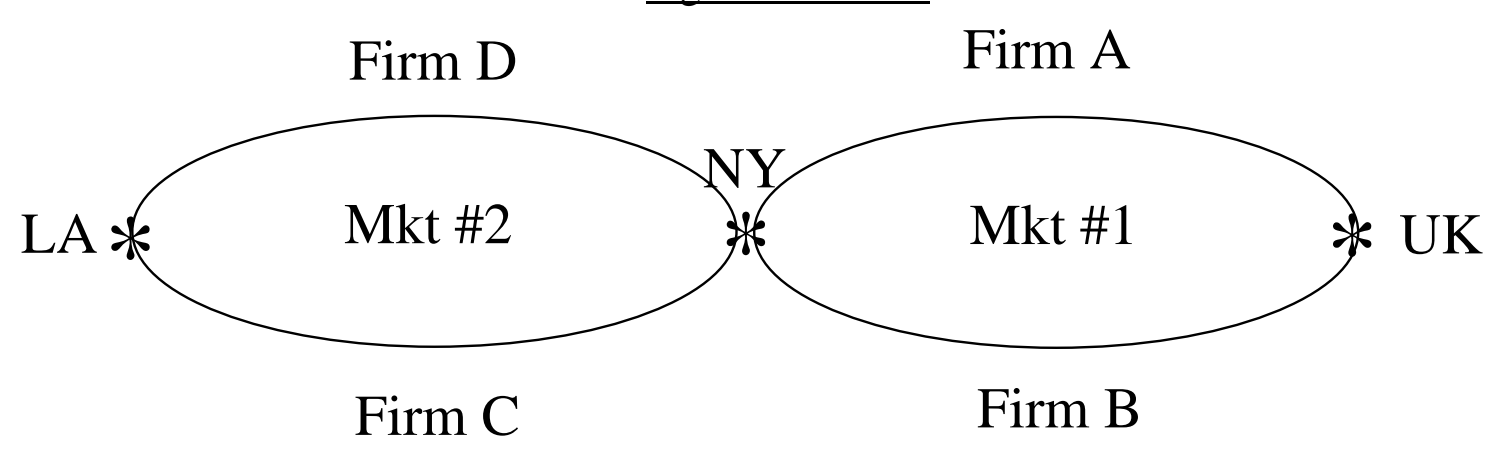


Figure 2: Case B

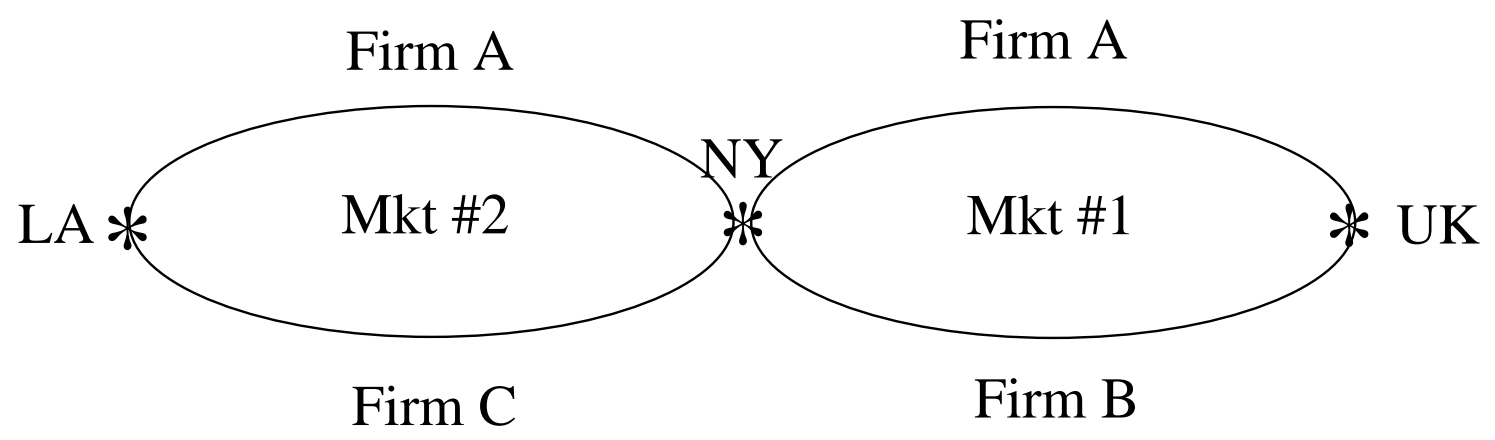


Figure 3: Case C

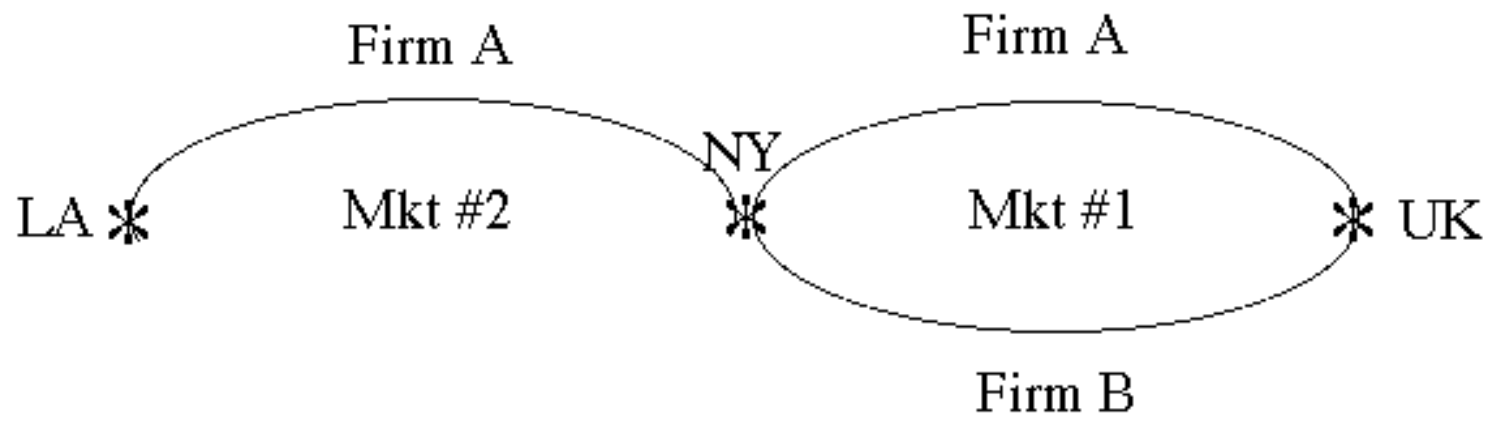




\begin{tabular}{|c|c|}
\hline \multicolumn{2}{|c|}{ Table 1: Variable Descriptions } \\
\hline Variables & Description \\
\hline $\begin{array}{l}\text { Domestic- } \\
\text { Network }\end{array}$ & An airline’s number of annual domestic departures \\
\hline $\begin{array}{l}\text { Domestic- } \\
\text { Dominance }\end{array}$ & $\begin{array}{l}\text { (An airline’s annual share of domestic passengers) / (Domestic } \\
\text { Herfindahl Index for that airline’s home domestic market) }\end{array}$ \\
\hline $\begin{array}{l}\text { International- } \\
\text { Market-Share }\end{array}$ & $\begin{array}{l}\text { An airline's annual share of the revenue passengers in an international } \\
\text { market segment }\end{array}$ \\
\hline Merger & \begin{tabular}{|l|} 
Dummy variable coded 1 for all years subsequent to the completion- \\
year of an airline's first domestic merger within the 1984-1992 period
\end{tabular} \\
\hline $\begin{array}{l}\text { Home- } \\
\text { Competitors }\end{array}$ & $\begin{array}{l}\text { Number of competitor airlines in an international market segment that } \\
\text { come from the home-nation of the focal airline }\end{array}$ \\
\hline $\begin{array}{l}\text { Foreign- } \\
\text { Competitors }\end{array}$ & $\begin{array}{l}\text { Number of competitor airlines in an international market segment that } \\
\text { come from a foreign-nation relative to the focal airline }\end{array}$ \\
\hline $\begin{array}{l}\text { International- } \\
\text { Network }\end{array}$ & An airline’s number of annual international departures \\
\hline
\end{tabular}




\begin{tabular}{|c|c|c|c|c|c|c|c|c|}
\hline Airlines & $\begin{array}{l}\text { Year of } 1^{s t} \\
\text { Merger }\end{array}$ & $\begin{array}{l}\# \\
\text { Obs. }\end{array}$ & $\begin{array}{l}\text { International- } \\
\text { Market-Share }\end{array}$ & $\begin{array}{c}\text { Domestic- } \\
\text { Dominance }\end{array}$ & $\begin{array}{l}\text { Domestic- } \\
\text { Network }\end{array}$ & $\begin{array}{c}\text { Home- } \\
\text { Competitors }\end{array}$ & $\begin{array}{c}\text { Foreign- } \\
\text { Competitors }\end{array}$ & $\begin{array}{c}\text { International- } \\
\text { Network }\end{array}$ \\
\hline Aerl. Argentinas & 1990 & 50 & 50.03 & 124.34 & 50,305 & 0 & 1.400 & 12,924 \\
\hline AerLingus & -- & 64 & 60.70 & 100.02 & 4,695 & 0.063 & 1.141 & 35,352 \\
\hline AeroMexico & -- & 130 & 30.79 & 87.68 & 65,504 & 0.415 & 1.546 & 14,483 \\
\hline Air Canada & -- & 232 & 50.11 & 133.15 & 120,306 & 0.138 & 1.129 & 40,987 \\
\hline Air France & 1988 & 972 & 45.31 & 24.31 & 23,879 & 0.015 & 1.158 & 156,621 \\
\hline Air UK & -- & 12 & 40.58 & 22.10 & 29,939 & 0.667 & 0.667 & 23,104 \\
\hline AirNewZealand & -- & 176 & 55.83 & 100.00 & 55,415 & 0 & 1.102 & 13,137 \\
\hline Alaska & 1986 & 44 & 34.61 & 11.34 & 105,487 & 0.364 & 1.318 & 7,348 \\
\hline Alitalia & -- & 830 & 47.35 & 92.60 & 44,900 & 0.005 & 1.070 & 72,285 \\
\hline All Nippon & -- & 20 & 29.45 & 141.82 & 160,745 & 1.000 & 1.500 & 6,661 \\
\hline American & 1987 & 277 & 44.73 & 151.53 & 690,602 & 0.874 & 1.036 & 73,035 \\
\hline Brit Airways & 1987 & 1,131 & 48.07 & 147.88 & 81,633 & 0.232 & 1.202 & 177,460 \\
\hline Brit Caledonia & -- & 82 & 17.37 & 16.40 & 12,610 & 0.902 & 1.244 & 22,341 \\
\hline Brit Midland & -- & 13 & 16.02 & 55.92 & 37,905 & 1.846 & 1.000 & 20,310 \\
\hline Britannia & 1988 & 6 & 6.98 & 4.30 & 1,295 & 1.000 & 1.000 & 1,069 \\
\hline Canadian & 1986 & 173 & 49.56 & 87.47 & 92,561 & 0.069 & 1.104 & 15,171 \\
\hline Continental & 1986 & 201 & 42.63 & 73.71 & 397,749 & 1.080 & 1.154 & 34,115 \\
\hline Cruziero & -- & 16 & 40.05 & 79.67 & 41,168 & 0.500 & 1.000 & 3,781 \\
\hline Delta & 1986 & 59 & 48.21 & 153.15 & 756,745 & 0.390 & 1.051 & 38,897 \\
\hline Eastern & -- & 76 & 33.71 & 105.14 & 388,495 & 0.724 & 0.816 & 34,852 \\
\hline Finnair & -- & 98 & 58.41 & 116.69 & 34,643 & 0 & 1.010 & 29,147 \\
\hline Frontier & -- & 4 & 57.37 & 24.10 & 100,642 & 1.000 & 0 & 3,558 \\
\hline Iberia & -- & 628 & 52.10 & 133.52 & 93,618 & 0.041 & 1.056 & 65,320 \\
\hline JAL & -- & 217 & 42.36 & 64.00 & 48,742 & 0.166 & 1.852 & 41,887 \\
\hline KLM & 1988 & 404 & 56.96 & 102.19 & 4,209 & 0 & 1.114 & 90,509 \\
\hline Ladeco & -- & 35 & 23.34 & 115.09 & 10,567 & 0.686 & 1.200 & 3,815 \\
\hline LanChile & -- & 20 & 49.76 & 95.07 & 9,621 & 0.900 & 1.250 & 6,250 \\
\hline Lufthansa & -- & 1,243 & 49.23 & 101.38 & 129,600 & 0.015 & 1.128 & 174,388 \\
\hline Mexicana & -- & 163 & 54.34 & 107.59 & 65,497 & 0.172 & 1.276 & 21,118 \\
\hline Northwest & 1986 & 190 & 35.30 & 72.08 & 387,208 & 1.368 & 1.068 & 32,939 \\
\hline Olympic & -- & 199 & 44.32 & 100.00 & 55,329 & 0 & 1.045 & 21,580 \\
\hline PacificSW & -- & 4 & 11.82 & 19.29 & 108,931 & 1.000 & 1.500 & 182 \\
\hline PanAm & -- & 402 & 35.61 & 18.78 & 70,961 & 1.032 & 1.127 & 73,261 \\
\hline Qantas & 1992 & 257 & 48.42 & 0 & 0 & 0 & 1.163 & 26,582 \\
\hline Republic & -- & 3 & 60.68 & 72.59 & 357,360 & 1.000 & 0 & 8,633 \\
\hline SwissAir & 1991 & 534 & 50.28 & 119.39 & 18,231 & 0 & 1.082 & 89,916 \\
\hline TAP & -- & 302 & 51.27 & 116.08 & 13,607 & 0.013 & 1.033 & 19,142 \\
\hline TWA & 1986 & 291 & 36.19 & 54.51 & 267,311 & 1.285 & 1.089 & 21,936 \\
\hline United & -- & 189 & 35.47 & 133.54 & 616,390 & 1.063 & 1.016 & 37,016 \\
\hline US Air & 1987 & 38 & 47.64 & 94.72 & 559,862 & 0.921 & 0.447 & 16,748 \\
\hline UTA & -- & 10 & 59.37 & 0 & 0 & 1.000 & 0.100 & 9,332 \\
\hline Varig & -- & 271 & 45.26 & 136.76 & 73,784 & 0.063 & 1.103 & 13,637 \\
\hline Virgin & -- & 48 & 21.62 & 0 & 0 & 1.042 & 3.000 & 3,338 \\
\hline Western & -- & 47 & 41.06 & 44.53 & 152,898 & 0.128 & 1.170 & 14,130 \\
\hline All Airlines & & 10,161 & 46.44 & 94.51 & 117,314 & 0.257 & 1.143 & 88,220 \\
\hline
\end{tabular}




\begin{tabular}{|c|c|c|c|c|}
\hline \multicolumn{5}{|c|}{$\begin{array}{l}\text { Table 3: Estimation Results for the Recursive Econometric Specification } \\
\text { * All Equations Incorporate Fixed 'Airline-Route', 'Airline-Country' \& 'Period' Effects }\end{array}$} \\
\hline $\begin{array}{l}\text { Explanatory } \\
\text { Variables }\end{array}$ & $\begin{array}{c}\text { OLS } \\
\text { Estimation }\end{array}$ & $\begin{array}{c}\text { SUR } \\
\text { Estimation }\end{array}$ & $\begin{array}{c}2 S L S \\
\text { Estimation }\end{array}$ & $\begin{array}{c}3 S L S \\
\text { Estimation }\end{array}$ \\
\hline \multicolumn{5}{|c|}{ Equation RES.1 (Dependent Variable = Domestic-Network) } \\
\hline Constant & $\begin{array}{l}-3500.50 * * \\
(1088)\end{array}$ & $\begin{array}{l}-3859.57 * * \\
(1085)\end{array}$ & $\begin{array}{l}-3500.50^{* *} \\
(1088)\end{array}$ & $\begin{array}{l}-3852.23^{* *} \\
(1085)\end{array}$ \\
\hline Merger & $9892.789 * *$ & $10340.28 * *$ & $9892.789 * *$ & $10336.57^{* *}$ \\
\hline International-Network $\mathrm{t}_{\mathrm{t}-1}$ & $\begin{array}{c}0.168457 * * \\
(0.0184)\end{array}$ & $\begin{array}{c}0.097428 * * \\
(0.0168)\end{array}$ & $\begin{array}{c}0.168457 * * \\
(0.0184)\end{array}$ & $\begin{array}{c}0.098156^{* *} \\
(0.0168)\end{array}$ \\
\hline Domestic-Network $\mathrm{t}-1$ & $\begin{array}{l}0.755446 * * \\
(0.0065)\end{array}$ & $\begin{array}{c}0.780817 * * \\
(0.0060)\end{array}$ & $\begin{array}{l}0.755446 * * \\
(0.0065)\end{array}$ & $\begin{array}{l}0.780730 * * \\
(0.0060)\end{array}$ \\
\hline Single-Equation R-Sqr & .64 & & .64 & \\
\hline \multicolumn{5}{|c|}{ Equation RES.2 (Dependent Variable = Domestic-Dominance) } \\
\hline Constant & $\begin{array}{c}1.506867 * * \\
(0.3607)\end{array}$ & $\begin{array}{l}1.507725^{* *} \\
(0.3607)\end{array}$ & $\begin{array}{l}1.506867 * * \\
(0.3607)\end{array}$ & $\begin{array}{l}1.506814 * * \\
(0.3607)\end{array}$ \\
\hline Merger & $\begin{array}{l}2.031798^{* *} \\
(0.3172)\end{array}$ & $\begin{array}{c}2.045160 * * \\
(0.3169)\end{array}$ & $\begin{array}{l}2.031798 * * \\
(0.3172)\end{array}$ & $\begin{array}{l}2.038416^{* *} \\
(0.3169)\end{array}$ \\
\hline Domestic-Dominance $_{\mathrm{t}-1}$ & $\begin{array}{c}0.651729 * * \\
(0.0078)\end{array}$ & $\begin{array}{c}0.646162 * * \\
(0.0071)\end{array}$ & $\begin{array}{c}0.651729 * * \\
(0.0078)\end{array}$ & $\begin{array}{l}0.646246^{* *} \\
(0.0071)\end{array}$ \\
\hline Single-Equation $R$-Sqr & .43 & & .43 & \\
\hline \multicolumn{5}{|c|}{ Equation RES.3 (Dependent Variable = International-Market-Share) } \\
\hline Constant & $\begin{array}{c}-1.97052 * * \\
(0.4605)\end{array}$ & $\begin{array}{c}-1.87715^{* *} \\
(0.4605)\end{array}$ & $\begin{array}{c}-1.96154^{* *} \\
(0.4595)\end{array}$ & $\begin{array}{c}-1.94756 * * \\
(0.4595)\end{array}$ \\
\hline Domestic-Network & $\begin{array}{c}0.000020^{* *} \\
(2.818 \mathrm{E}-6)\end{array}$ & $\begin{array}{l}0.000023^{* *} \\
(2.817 \mathrm{E}-6)\end{array}$ & $\begin{array}{l}0.000023 * * \\
(3.576 \mathrm{E}-6)\end{array}$ & $\begin{array}{l}0.000024^{* *} \\
(3.575 \mathrm{E}-6)\end{array}$ \\
\hline Domestic-Dominance & $\begin{array}{c}0.049775 * * \\
(0.0102)\end{array}$ & $\begin{array}{c}0.034720 * * \\
(0.0102)\end{array}$ & $\begin{array}{l}0.033157^{*} \\
(0.0158)\end{array}$ & $\begin{array}{c}0.031957^{*} \\
(0.0158)\end{array}$ \\
\hline Home-Competitors & $\begin{array}{l}-9.65382 * * \\
(0.5784)\end{array}$ & $\begin{array}{l}-9.69047^{* *} \\
(0.5783)\end{array}$ & $\begin{array}{l}-9.67951^{* *} \\
(0.5799)\end{array}$ & $\begin{array}{l}-9.65179 * * \\
(0.5795)\end{array}$ \\
\hline (Home-Competitors) $^{2}$ & $\begin{array}{l}1.359866^{* *} \\
(0.1398)\end{array}$ & $\begin{array}{c}1.353376^{* *} \\
(0.1397)\end{array}$ & $\begin{array}{c}1.355427^{* *} \\
(0.1399)\end{array}$ & $\begin{array}{c}1.351183^{* *} \\
(0.1398)\end{array}$ \\
\hline Foreign-Competitors & $\begin{array}{c}-25.9279 * * \\
(0.6038)\end{array}$ & $\begin{array}{c}-25.9128 * * \\
(0.6036)\end{array}$ & $\begin{array}{l}-25.8848 * * \\
(0.6044)\end{array}$ & $\begin{array}{l}-25.8904 * * \\
(0.6039)\end{array}$ \\
\hline (Foreign-Competitors) $^{2}$ & $\begin{array}{l}4.128725^{* *} \\
(0.1311)\end{array}$ & $\begin{array}{c}4.127486^{* *} \\
(0.1311)\end{array}$ & $\begin{array}{l}4.129876 * * \\
(0.1313)\end{array}$ & $\begin{array}{c}4.126842 * * \\
(0.1312)\end{array}$ \\
\hline $\begin{array}{l}\text { International-Market- } \\
\text { Share }{ }_{t-1}\end{array}$ & $\begin{array}{l}0.271808^{* *} \\
(0.0071)\end{array}$ & $\begin{array}{l}0.271531^{* *} \\
(0.0071)\end{array}$ & $\begin{array}{l}0.272538 * * \\
(0.0071)\end{array}$ & $\begin{array}{l}0.272147^{* *} \\
(0.0071)\end{array}$ \\
\hline Single-Equation R-Sqr & .33 & & .33 & \\
\hline $\begin{array}{l}\text { System Weighted R-Sqr } \\
\text { Observations }\end{array}$ & 10.161 & $\begin{array}{c}.52 \\
10.161\end{array}$ & 10.161 & $\begin{array}{c}.52 \\
10.161\end{array}$ \\
\hline
\end{tabular}




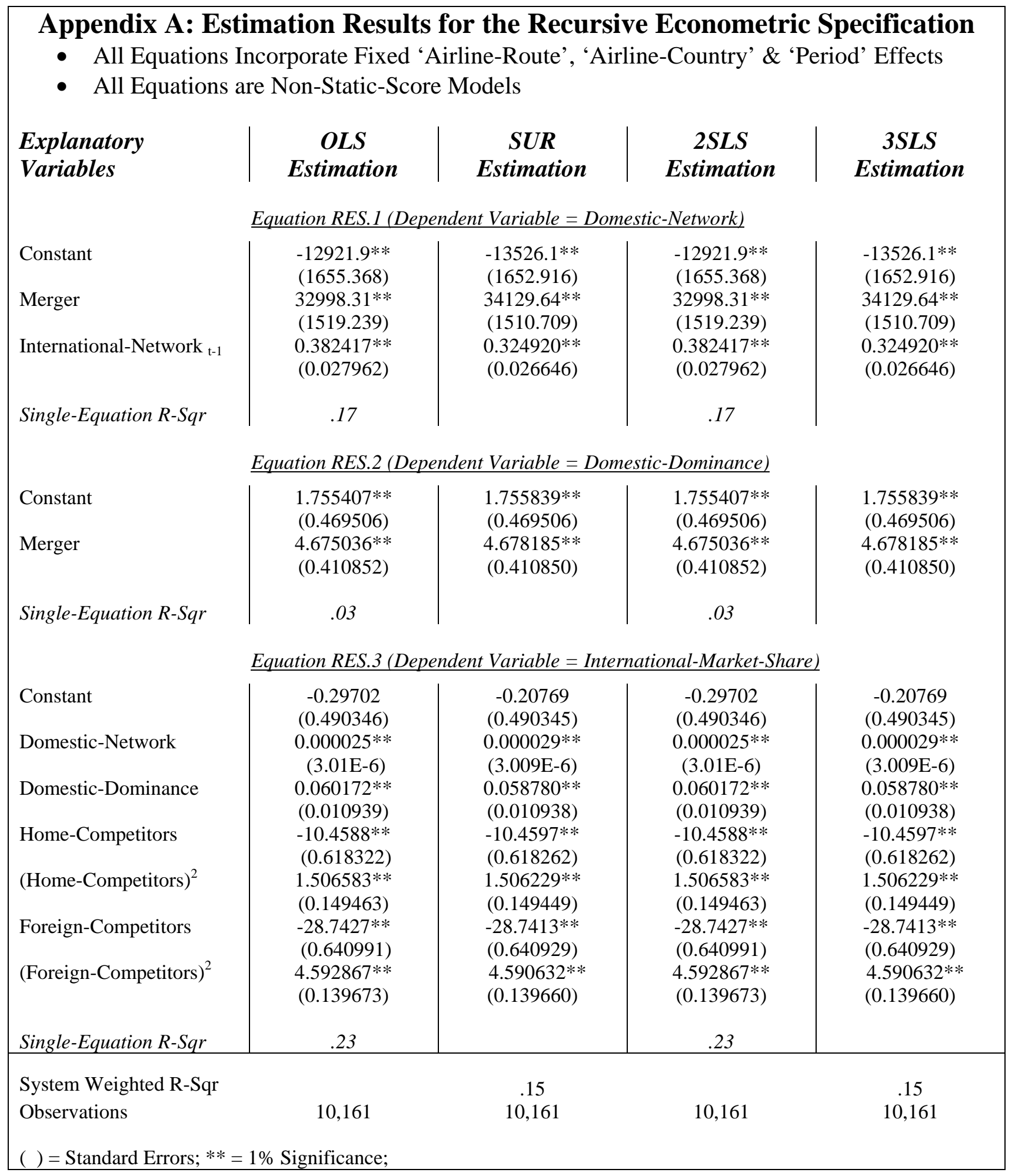


Bücher des Forschungsschwerpunkts Markt und politische Ökonomie

Books of the Research Area Markets and Political Economy

Pablo Beramendi

Decentralization and Income Inequality

2003, Madrid: Juan March Institute

Thomas Cusack

A National Challenge at the Local Level: Citizens, Elites and Institutions in Reunified Germany

2003, Ashgate

Sebastian Kessing

Essays on Employment Protection

2003, Freie Universität Berlin,

http://www.diss.fu-berlin.de/2003/202

Daniel Krähmer

On Learning and Information in Markets and

Organizations

2003, Shaker Verlag

Bob Hancké

Large Firms and Institutional Change. Industrial

Renewal and Economic Restructuring in France

2002, Oxford University Press

Andreas Stephan

Essays on the Contribution of Public Infrastruc-

ture to Private: Production and its Political

Economy

2002, dissertation.de

Peter A. Hall, David Soskice (Eds.)

Varieties of Capitalism

2001, Oxford University Press

Hans Mewis

Essays on Herd Behavior and Strategic Delegation

2001, Shaker Verlag

Andreas Moerke

Organisationslernen über Netzwerke - Die

personellen Verflechtungen von Führungsgremien

japanischer Aktiengesellschaften

2001, Deutscher Universitäts-Verlag

Silke Neubauer

Multimarket Contact and Organizational Design

2001, Deutscher Universitäts-Verlag

Lars-Hendrik Röller, Christian Wey (Eds.)

Die Soziale Marktwirtschaft in der neuen

Weltwirtschaft, WZB Jahrbuch 2001

2001, edition sigma

Michael Tröge

Competition in Credit Markets: A Theoretic

Analysis

2001, Deutscher Universitäts-Verlag

Torben Iversen, Jonas Pontusson, David Soskice

(Eds.)

Unions, Employers, and Central Banks

2000, Cambridge University Press
Tobias Miarka

Financial Intermediation and Deregulation:

A Critical Analysis of Japanese Bank-Firm-

Relationships

2000, Physica-Verlag

Rita Zobel

Beschäftigungsveränderungen und

organisationales Lernen in japanischen

Industriengesellschaften

2000, Humboldt-Universität zu Berlin

http://dochost.rz.hu-berlin.de/dissertationen/zobel-rita2000-06-19

Jos Jansen

Essays on Incentives in Regulation and Innovation 2000, Tilburg University

Ralph Siebert

Innovation, Research Joint Ventures, and

Multiproduct Competition

2000, Humboldt-Universität zu Berlin

http://dochost.rz.hu-berlin.de/dissertationen/siebert-

ralph-2000-03-23/

Damien J. Neven, Lars-Hendrik Röller (Eds.)

The Political Economy of Industrial Policy in

Europe and the Member States

2000, edition sigma

Jianping Yang

Bankbeziehungen deutscher Unternehmen:

Investitionsverhalten und Risikoanalyse

2000, Deutscher Universitäts-Verlag

Christoph Schenk

Cooperation between Competitors -

Subcontracting and the Influence of Information,

Production and Capacity on Market Structure and

Competition

1999, Humboldt-Universität zu Berlin

http://dochost.rz.hu-berlin.de/dissertationen/schenkchristoph-1999-11-16

Horst Albach, Ulrike Görtzen, Rita Zobel (Eds.)

Information Processing as a Competitive

Advantage of Japanese Firms

1999, edition sigma

Dieter Köster

Wettbewerb in Netzproduktmärkten

1999, Deutscher Universitäts-Verlag

Christian Wey

Marktorganisation durch Standardisierung: Ein

Beitrag zur Neuen Institutionenökonomik des

Marktes

1999, edition sigma 
Jos Jansen

Johan Lagerlöf

Lars Frisell

Sigurt Vitols

Lutz Engelhardt

Antonio Guarino

Steffen Huck

Thomas D. Jeitschko

Thomas Plümper

Vera E. Troeger

Ulrich Kaisera

Pablo Beramendi Thomas R. Cusack Joseph Clougherty

Joseph Clougherty Anming Zhang

Roel C.A. Oomen

Robert J. Franzese,Jr. Jude C. Hays

Albert Banal-Estañol Inés Macho-Stadler Jo Seldeslachts

Oz Shy Rune Stenbacka Jonathan Beck

Michal Grajek

Paul Heidhues Botond Kőszegi

Chiara Strozzi

Olivier Gossner Nicolas Melissas
Partial Information Sharing in Cournot Oligopoly

Lobbying, Information Transmission, and Unequal Representation

Changes in Germany's Bank Based Financial System: A Varieties of Capitalism Perspective

Entrepreneurial Business Models in the German Software Industry: Companies, Venture Capital, and Stock Market Based Growth Strategies of the ,Neuer Markt'

Can Fear Cause Economic Collapse? Insights from an Experimental Study

External Effects of Currency Unions

An Estimated Model of the German Magazine Market

Diverse Disparities: The Politics and Economics of Wage, Market and Disposable Income Inequalities

Antitrust Holdup Source, Cross-National Institutional Variation, and Corporate Political Strategy Implications for Domestic Mergers in a Global Context

Export Orientation and Domestic Merger Policy: Theory and Some Empirical Evidence

Modelling Realized Variance when Returns are Serially Correlated

Modeling International Diffusion: Inferential Benefits and Methodological Challenges, with an Application to International Tax Competition

Mergers, Investment Decisions and Internal Organisation

Price Competition, Business Hours, and Shopping Time Flexibility

Fixed, focal, fair? Book Prices Under Optional resale Price Maintenance

Diffusion of ISO 9000 Standards and International Trade

The Impact of Consumer Loss Aversion on Pricing

Citizenship Laws and International Migration in Historical Perspective

Informational Cascades Elicit Private Information
SP I| 2004- 06

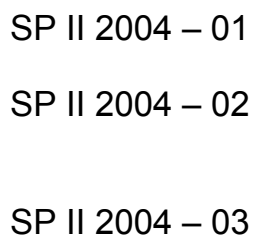

SP || $2004-19$ 
Lutz Engelhardt Geschäftsmodelle und nationale Institutionen: Ein Vergleich britischer und deutscher Neuemissionen aus der IT-Service - und Softwareindustrie 1996 2002

Philipp Rehm

Sigurt Vitols Lutz Engelhardt

Sebastian G. Kessing

Kai A. Konrad

Kai A. Konrad Amedeo Spadaro

Joseph A. Clougherty
Determinants of Support for Income Redistribution

National Institutions and High Tech Industries:

A Varieties of Capitalism Perspective on the Failure of Germany's "Neuer Markt"

Union Strategy and Optimal Income

Taxation

Education, Redistributive Taxation, and Confidence

The International Drivers of Domestic Airline Mergers in Twenty Nations: Integrating Industrial Organization and International Business
SP || $2005-01$

SP || 2005- 02

SP II $2005-03$

SP || $2005-04$

SP || $2005-05$

SP II 2005-06 
Bei Ihren Bestellungen von WZB-Papers schicken

Sie bitte unbedingt einen an Sie adressierten Auf-

kleber mit sowie je paper eine Briefmarke im Wert

von 0,51 Euro oder einen "Coupon Reponse Inter-

national " (für Besteller aus dem Ausland)
Please send a self addressed label and postage stamps in the amount of 0.51 Euro or a "CouponReponse International" (if you are ordering from outside Germany) for each WZB-paper requested

Absender I Return Address:

Wissenschaftszentrum Berlin

für Sozialforschung

Presse- und informationsreferat

Reichpietschufer 50

D-10785 Berlin-Tiergarten

Hiermit bestelle ich folgende(s)

Discussion paper(s):

Please send me the following Discussion paper(s):

Bestell-Nr. I Order no.

Autor/in, Kurztitel /Author(s) / Title(s) in brief 